Article

\title{
Biogas, Solar and Geothermal Energy-The Way to a Net-Zero Energy Wastewater Treatment Plant-A Case Study
}

\author{
Sylwia Myszograj ${ }^{1, *(1)}$, Dariusz Bocheński ${ }^{2}$, Mirosław Mąkowski ${ }^{3}$ and Ewelina Płuciennik-Koropczuk ${ }^{1}$ (I) \\ 1 Institute of Environmental Engineering, University od Zielona Góra, 65-001 Zielona Góra, Poland; \\ E.Pluciennik@iis.uz.zgora.pl \\ 2 Wastewater Treatment Enterprise Gubin-Guben, 66-620 Gubin, Poland; Dariusz.Bochenski@gmail.com \\ 3 Comeko Sp. z o.o., 65-001 Zielona Góra, Poland; biuro@comeko.zgora.pl \\ * Correspondence: S.Myszograj@iis.uz.zgora.pl; Tel.: +48-683282574
}

check for

updates

Citation: Myszograj, S.; Bocheński, D.; Mąkowski, M.; Płuciennik-Koropczuk,

E. Biogas, Solar and Geothermal

Energy-The Way to a Net-Zero

Energy Wastewater Treatment

Plant-A Case Study. Energies 2021,

14, 6898. https://doi.org/10.3390/

en14216898

Academic Editors: Manolis Souliotis and Pierluigi Siano

Received: 27 September 2021

Accepted: 18 October 2021

Published: 21 October 2021

Publisher's Note: MDPI stays neutral with regard to jurisdictional claims in published maps and institutional affiliations.

Copyright: (C) 2021 by the authors. Licensee MDPI, Basel, Switzerland. This article is an open access article distributed under the terms and conditions of the Creative Commons Attribution (CC BY) license (https:/ / creativecommons.org/licenses/by/ $4.0 /)$.

\begin{abstract}
Wastewater treatment plants designed to meet the requirements of discharging wastewater to a receiving water body are often not energy optimised. Energy requirements for conventional activated sludge wastewater treatment plants are estimated to range from 0.30 to $1.2 \mathrm{kWh} / \mathrm{m}^{3}$, with the highest values achieved using the nitrification process. This article describes the energy optimisation process of the wastewater treatment plant in Gubin (Poland) designed for 90,000 PE (population equivalent) using renewable energy sources: solar, biogas, and geothermal. At the analysed wastewater treatment plant electricity consumption for treating $1 \mathrm{~m}^{3}$ of wastewater was $0.679 \mathrm{kWh}$ in 2020. The combined production of electricity and heat from biogas, the production of electricity in a photovoltaic system, and heat recovery in a geothermal process make it possible to obtain a surplus of heat in relation to its demand in the wastewater treatment plant, and to cover the demand for electricity, with the possibility of also selling it to the power grid.
\end{abstract}

Keywords: wastewater treatment plant; solar energy; biogas; geothermal energy; energy balance

\section{Introduction}

Energy efficiency in the water and wastewater industry has become increasingly important in recent years, as wastewater treatment plants are responsible for nearly $35 \%$ of the energy consumption of all municipal facilities [1]. Discharging treated wastewater into receiving bodies in compliance with current legal requirements necessitates the use of efficient pollution removal technologies and sludge treatment processes. Optimal operation of wastewater treatment plants requires the provision of electricity, which is necessary for conducting technological processes as well as for transporting wastewater. The highest demand for electricity is associated with biological wastewater treatment, e.g., in systems with activated sludge where the consumption of electricity for aerating bioreactors is at the level of $50-70 \%[2,3]$. Next, about $35 \%$ is the electricity consumption for the sewage sludge treatment processes, which depend on the technology adopted and the equipment used. The energy demand of the wastewater treatment plant (WWTP) also depends on the size of the installation (Table 1) and the technology used for a given wastewater characteristic as well as the required effluent quality.

Table 1. Specific energy consumption in dependency of WWTP capacity in actual population equivalents (PE) [4]. Reprint with permission [CC BY]; 2020, Gruber-Glatzl, Brunner, Meitz and Schnitzer.

\begin{tabular}{ccc}
\hline $\begin{array}{c}\text { Range of Actual Population } \\
\text { Equivalents }\end{array}$ & $\begin{array}{c}\text { Analyzed Number of WWTP } \\
\text { in Range }\end{array}$ & $\begin{array}{c}\text { Specific Energy } \\
\text { Consumption [kWh/PE/y] }\end{array}$ \\
\hline$<20,000$ & 99 & 96 \\
$20,000-50,000$ & 26 & 48 \\
$>50,000$ & 52 & 37 \\
\hline
\end{tabular}


A conventional municipal WWTP usually consists of primary, secondary and advanced stages. Typically, the energy requirement for conventional activated wastewater treatment plants ranges from $0.30 \mathrm{kWh} / \mathrm{m}^{3}$ to $1.2 \mathrm{kWh} / \mathrm{m}^{3}$, with the highest values achieved with the nitrification process due to the need to operate an aeration system [3]. Running the wastewater treatment process with chemical or chemical-physical methods increases the electricity consumption to 1.3 and even $2.8 \mathrm{kWh} / \mathrm{m}^{3}$, respectively [5]. In the $\mathrm{EU}$, power consumption is in the range between $0.3-2.1 \mathrm{kWh} / \mathrm{m}^{3}$ of treated wastewater, and 0.41 to $0.87 \mathrm{kWh} / \mathrm{m}^{3}$ in the U.S. Current technology levels indicate that specific power consumption should range between 20 and $45 \mathrm{kWh}$ per PE per year. With some nonmodernized WWTP, operating in old technologies may double these energy demands $[6,7]$.

The costs generated translate into the price of collecting and treating wastewater [8]. Therefore, it is justified to optimize the wastewater treatment processes technically and economically by reducing the electricity consumption rates; however, the reduction of the energy intensity of these processes is possible only within certain limits. Therefore, it is necessary, apart from rationalisation of consumption, to look for other methods of obtaining energy. One of the ways of solving this problem and at the same time reducing the emission of harmful combustion products and slowing down the rate of consumption of fossil fuel resources is the use of "clean" technologies of energy generation, in particular the so-called "renewable" energy sources. A renewable energy source is a source that, in the process of energy production, uses wind energy, solar radiation, geothermal energy, waves, sea currents and tides, fall of rivers, and energy obtained from biomass, biogas from landfill, or from the process of anaerobic digestion of sewage sludge.

Currently, the global world production of wastewater reach 380 billion $\mathrm{m}^{3}$. Among the regions in the world, the greatest amount of wastewater is generated by Asia (159 billion $\mathrm{m}^{3}$, $42 \%$ of global amount), North America $\left(67\right.$ billion $\left.\mathrm{m}^{3}\right)$ and Europe $\left(68\right.$ billion $\left.\mathrm{m}^{3}\right)$. It is expected that the amount of wastewater generated will reach 574 billion $\mathrm{m}^{3}(51 \%$ increase over the current level) in 2050 [9]. For this reason, the energy requirement for this purpose should also increase. The European Union has adopted the 2030 climate and energy framework and has set EU-wide targets and policy targets for 2030 as a $40 \%$ reduction in greenhouse gas emissions compared to 1990 levels, and a minimum share of $27 \%$ in renewable energy consumption. In the longer term, in 2050 the share of renewable energy may be between $55 \%$ and $75 \%$ of gross final energy consumption in the European Union $[10,11]$.

Energy management strategies in municipal wastewater treatment plants commonly include renewable energy production on site. Wastewater and sewage sludge are good material for anaerobic digestion processes, heat recovery and hydropower. The area of the WWTPs is suitable for the use of solar panels (Figure 1).

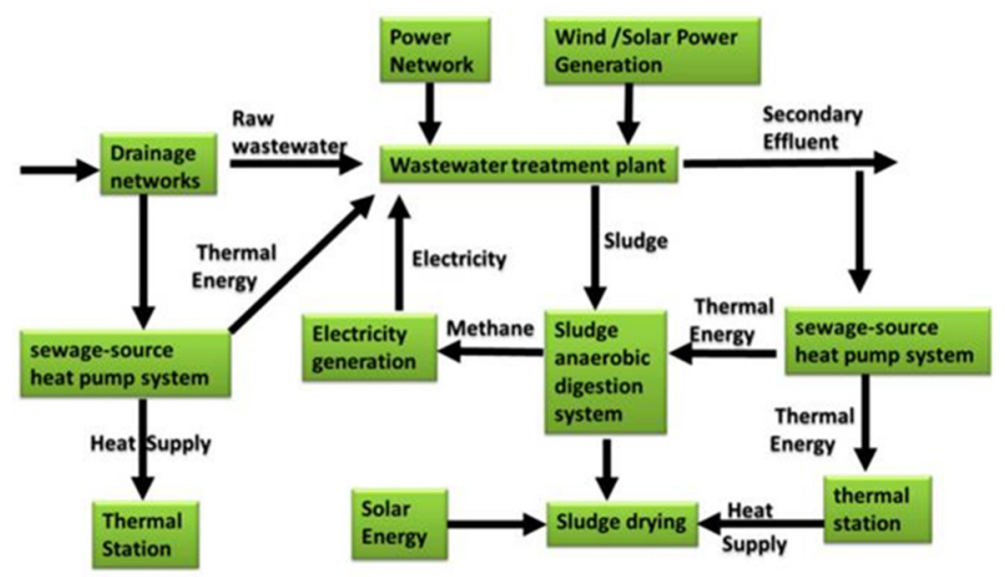

Figure 1. Energy utilization diagram of a wastewater treatment plant [12]. Reprint with permission [CC BY]; 2019, Licensee MDPI, Basel, Switzerland. 
Anaerobic digestion process convert organic matter from raw wastewater and sludge into methane-rich biogas. The content of methane and carbon dioxide in biogas varies depending on the substrates and ranges, respectively, 45-80\% $\mathrm{CH}_{4}$ and $34-55 \% \mathrm{CO}_{2}$ [13]. Myszograj conducted research, which indicated the possibility of an increase in the biogas and methane potential of excess sludge and bio-waste as a result of the thermal disintegration process $[14,15]$.

Utilize biogas can be used for heating the wastewater treatment reactors and generating electricity [16-20]. According to the data of the Central Statistical Office for 2018, there were approximately $72 \mathrm{MW}$ of electric power installed in Poland using biogas from WWTPs, which allowed to generate approximately 337 GWh of electricity and approximately 160 TJ of heat [21]. An overview of the development and prospects of biogas in the European Union (EU) and its Member States is described by Scarlat et al., 2018 [22]. The world leader in the production of electricity from biogas is the EU. It has more than $10 \mathrm{GW}$ and 17,400 biogas plants installed, compared to a global biogas capacity of 15 GW in 2015 . Looking at the sources of biogas, anaerobic digesters biogas predominates in Germany, Italy, Denmark, Czech Republic and Austria. In Portugal, Estonia, Ireland, Greece and Great Britain, biogas from landfills dominates the energy market. On the other hand, biogas obtained from sewage treatment plants is prevalent in a few countries, such as Sweden, Poland and Lithuania [22]. Most wastewater treatment plants in Austria with a capacity of $>20,000 \mathrm{PE}$ have a digestion tank and produce biogas [4]. In Poland, only 140 of 2500 WWTP are equipped with installations for anaerobic digestion of sewage sludge $(6 \%$ of all WWTP's) [2].

Wastewater is also a source of mostly untapped thermal energy [23]. Thermal energy recovery from wastewater implies the extraction of heat from the consumed water, and depends upon the temperature drop of effluent after energy recovery [24]. In WWTPs, the heat recovery points can be raw wastewater before treatment, partially treated wastewater, and effluent discharge after treatment [8]. The treated wastewater is a very good source, because the water flow is higher. Minor water temperature fluctuations affect the efficiency of the heat pump systems. Low concentration of solids means less biofouling and interference in the heat exchanger, thus improving the efficiency of heat exchange [25]. Studies by Hao et al. [26] confirmed that water heat pumps can deliver a net electrical equivalent of $0.26 \mathrm{kWh}$ when $1 \mathrm{~m}^{3}$ of waste water is cooled by $1 \mathrm{~K}$. The heat energy can be directly used when it is used for heating, while it is used indirectly for production electricity [27]. The research conducted by Pochwała and Kotas [28] showed that the heat recovered from raw sewage satisfied $98 \%$ of the heat demand necessary for a sequential biological reactor (SBR) up to the optimum temperature value for the treatment process. The use of solar energy is growing fastest of all sources. This means that solar electricity grew from just 7.4 TWh in 2008 to 125.7 TWh in 2019 [29-31]. WWTPs are covering large areas and therefore the potential in solar energy contribution from WWTPs is relatively high. Photovoltaic (PV) panels are predicted to provide $5 \%$ of the world's electricity consumption in 2030 and $11 \%$ in 2050 [32]. The energy generated from photovoltaic power plants can be used and consumed in wastewater treatment plants. The combination of photovoltaic energy production and wastewater treatment as well as the implementation of an energy management system can significantly reduce the costs of wastewater treatment [12,32]. Use of solar energy instead of traditional energy in WWTP was described by Strazzabosco et al. [33]. Research conducted at 105 wastewater treatment plants in California showed that solar PV often represented the only source of renewable energy. The reported production ranges from 30 to $100 \%$ of the energy requirements of these WWTPs [33].

The use of geothermal energy depends on the source temperature. Geothermal sources are classified as low-enthalpy (lower than $100^{\circ} \mathrm{C}$ ), medium enthalpy (between 100 and $150^{\circ} \mathrm{C}$ ) and high enthalpy (higher than $150^{\circ} \mathrm{C}$ ) [34]. When the temperature sources are higher than $90^{\circ} \mathrm{C}$, electricity generation is prior to thermal uses, for lower temperature, only thermal uses are considered [35]. In southern Italy, low- and medium-enthalpy geothermal sources were used, to generate electricity and to dry the sludge. The system covers $100 \%$ of 
the WWTPs electricity requirements with the production of $1.68 \mathrm{kWh}$ per $\mathrm{kg}$ of processed sludge. The simple payback time is about 5 years and a $\mathrm{CO}_{2}$ equivalent emission saving of 628 tons/year [27].

An analysis of energy consumption and recovery from renewable sources in various wastewater treatment plants around the world showed that in some cases it is possible to achieve an energy independence [36,37].

Practical implementation of green technology in WWTPs described by Guo et al. [12] showed that the WWTP in Eastern China (capacity 800,000 ton/day) generate electricity for onsite using solar photovoltaic power technology and produce $1.04 \times 107 \mathrm{kWh}$ of electricity (84\% of total energy demand). WWTP in the UK (capacity 63,000 ton/day) can generate $96 \%$ of the total energy consumption through biogas. WWTP in Ireland produces $7.6 \times 104 \mathrm{kWh}$ (50\% of annual energy use). WWTP in Austria (capacity 228,000 ton/day) fully fills the demand of energy using biogas technology.

The article describes the process of energy optimization of a wastewater treatment plant designed for 90,000 PE using renewable energy sources being solar, biogas, and geothermal.

\section{The Gubin-Guben Wastewater Treatment Plant}

The joint German-Polish Wastewater Treatment Plant (WWTP) was put into operation on 2 May 1998 and is located in Gubin (Poland). A view of the WWTP facilities is shown in Figure 2. Wastewater from the towns of Gubin (Poland) and Guben (Germany) is fed into the plant. The Lusatian Neisse is the recipient of the treated wastewater.
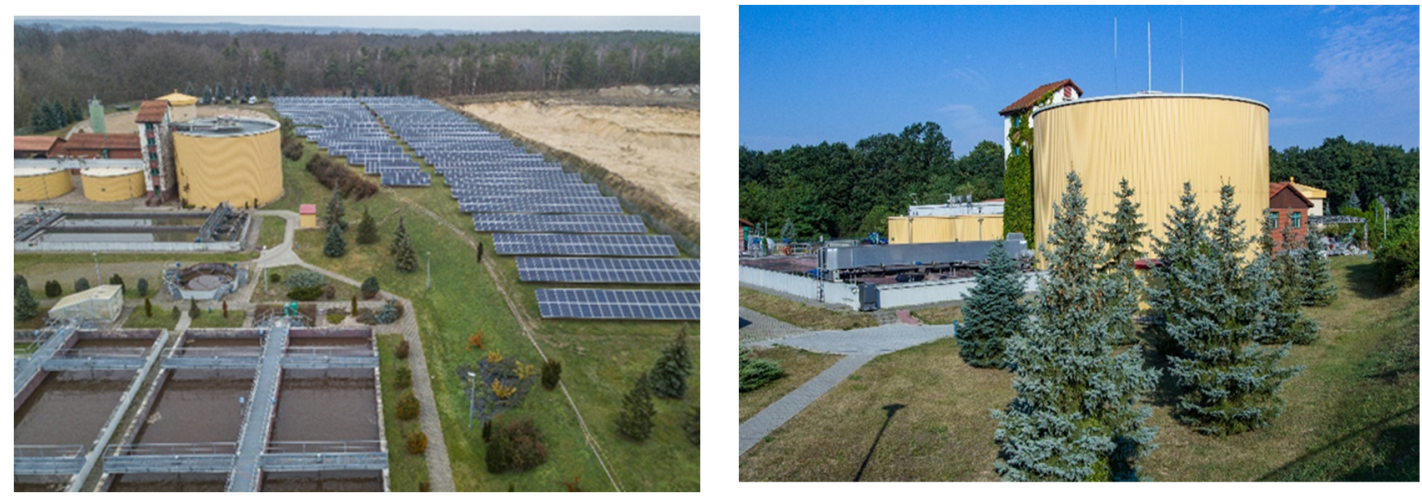

Figure 2. View of the Gubin-Guben WWTP (photo by WWTP's Archive).

The Gubin-Guben WWTP is a mechanical-biological treatment plant designed for $90,000 \mathrm{PE}$ and a daily average flow of $12,000 \mathrm{~m}^{3} / \mathrm{d}$ (dry weather). Gubin is working with $95 \%$ of combined sewer and 5\% storm sewer, and in Guben there is $90 \%$ of sanitary and storm sewer and $10 \%$ combined sewer.

The maximum hydraulic load (70\%) of the WWTP was achieved in 2010, with a decreasing trend in subsequent years. On average, in the period 1999-2021, this parameter was $58 \%$, and in 2020,53\% (Figure 3). In 2020, the average volume of wastewater coming into the plant from Guben was $3591 \mathrm{~m}^{3} / \mathrm{d}$, and from Gubin, $3523 \mathrm{~m}^{3} / \mathrm{d}$.

In the bar screens building, the quantity of wastewater from pressure pipes from Guben $(1 \times \Phi 400 \mathrm{~mm}, 1 \times \Phi 300 \mathrm{~mm})$ and Gubin $(\Phi 400 \mathrm{~mm})$ is measured by means of induction flow measurement. In the three chambers where wastewater flows in, "on-line" measuring devices are installed (measurement of $\mathrm{pH}$ value, temperature, and conductivity) as well as devices automatically taking wastewater for analytic purposes. In the mechanical section of the WWTP, there are step screens $\left(Q_{\max }=300 \mathrm{~L} / \mathrm{s}\right)$, an aerated sand trap, and a primary clarifier $\left(\mathrm{V}_{\mathrm{cz}}=540 \mathrm{~m}^{3}\right)$. Wastewater devoid of solids, sand, and suspended solids is directed to the biological section operating with activated sludge technology with nutrient removal. The biological reactor consists of four parallel chambers. In each chamber, there is a defosfatation zone, two denitrification zones, and three nitrification zones. The primary coagulant dosing point for chemical phosphorus precipitation is the separation 
chamber before the secondary settling tanks. After the sedimentation process in the two secondary settling tanks, the treated wastewater is led to the outlet channel through a double-sided overflow. The excess sludge is mechanically thickened from 1 to $6-7 \%$ of the dry matter and is further thickened together with the primary sludge in the gravity thickener and, after heating, is directed to the fermentation bioreactor. The fermentation process is carried out for about 15 days at a temperature of $37^{\circ} \mathrm{C}$. The fermentation gas is directed to a pressureless gas tank with a capacity of $500 \mathrm{~m}^{3}$. The gas receivers in the plant are gas engines with an electricity generator, central heating boiler, and gas flare. The digested sludge is pumped into the gravitation thickener. After reaching a suitable degree of thickening, the sludge is fed into centrifuges. After centrifugation, the sludge is hygienised with highly reactive lime. The sludge thus prepared, containing approximately $20-23 \%$ of the dry matter, is used for agricultural purposes. The technological scheme is shown in Figure 4.

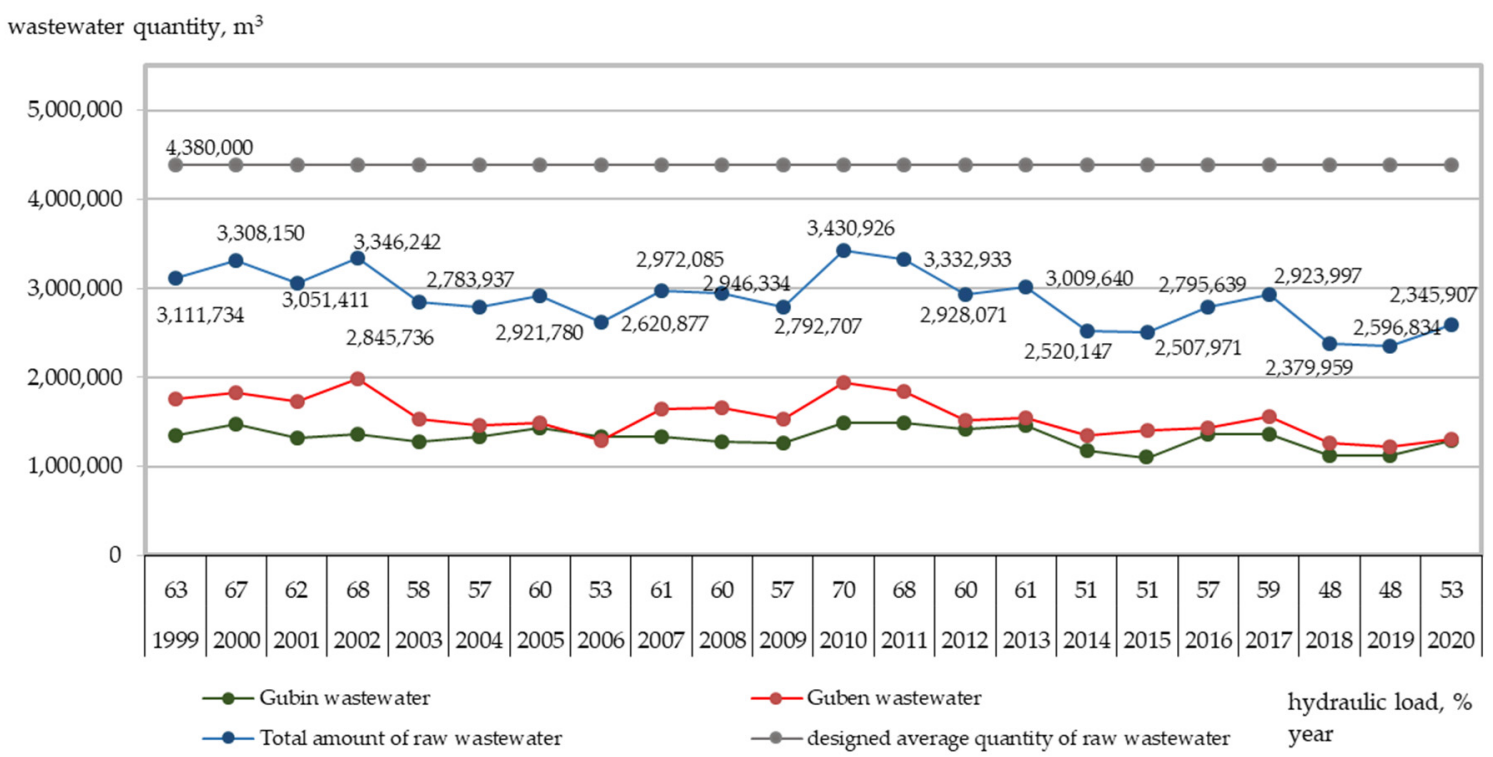

Figure 3. Quantity of raw wastewater inflowing to the Gubin-Guben WWTP in the years 1999-2020.

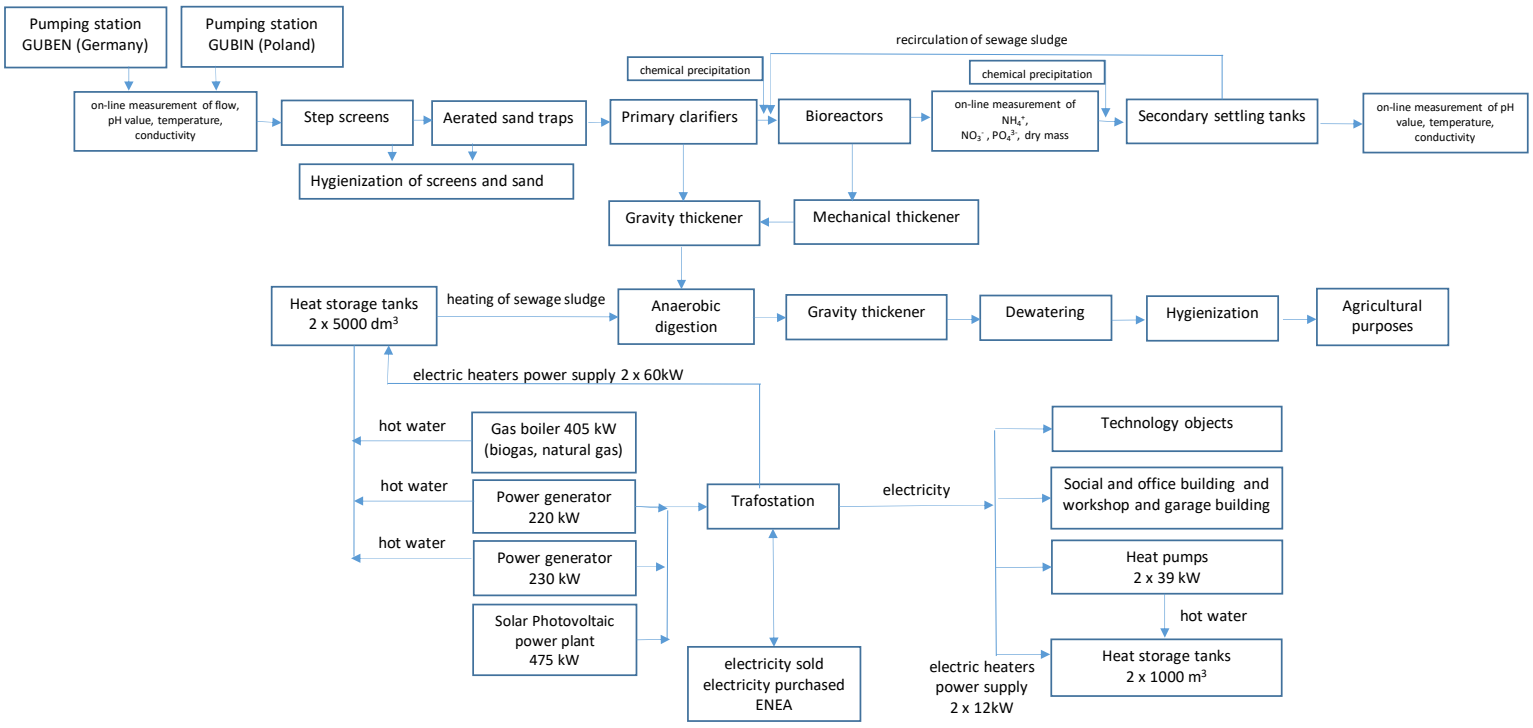

Figure 4. The technological scheme of Gubin-Guben WWTP. 


\section{Results}

In a wastewater treatment plant, as in many other industrial sectors, the largest cost factor is the electricity and heat consumed, as well as other utilities required to secure the operation of the processing system. The development of energy hybrids that make dependence on external energy sources as independent as possible is a direction that has been consistently pursued at the Gubin-Guben Wastewater Treatment Plant. The project for a joint wastewater treatment plant for the towns of Gubin and Guben already included the possibility of recovering electricity and heat through the process of methane fermentation of sewage sludge.

\subsection{Step One-Optimisation of Biogas Production and Use}

Since the beginning of its operation, the WWTP has been equipped with a generating set with an electric capacity of $230 \mathrm{~kW}$ and a thermal capacity of $280 \mathrm{~kW}$, and with a gas boiler with a thermal capacity of $405 \mathrm{~kW}$. In 1999/2000, the gas boiler was fired by biogas from the digester or by fuel oil, while the combustion engine was only powered by biogas. This allowed the WWTP to generate only $16-18 \%$ of its own electricity and secure $100 \%$ of the heat needed to heat the facilities and maintain the technological processes.

Additionally, the conditions for connection to the power grid allowed the WWTP to produce only $80 \%$ of its power in the generating set, and $20 \%$ of the power had to be purchased from the electricity supplier (ENEA-the proper name of a Polish company in the energy sector, vice-leader in the production of electricity in Poland), with no possibility of feeding electricity into the grid. In 2002, a natural gas connection was made, and an application was made to ENEA to change the conditions for electricity connection. The maximum production of electricity and heat in the generating set was assumed, with the maximum use of energy for the plant's own needs, with the possibility of transferring the surplus to the power grid of ENEA. This change in the conditions and operation of the power system has brought tangible economic benefits (Table 2).

Table 2. Comparison of the energy balance of the Gubin-Guben WWTP, 2001 and 2002.

\begin{tabular}{|c|c|c|c|c|}
\hline & Parameter & Unit & 2001 & 2002 \\
\hline \multicolumn{2}{|c|}{ Heat Demand Coverage } & $\%$ & 90 & 100 \\
\hline \multicolumn{2}{|r|}{ Electricity } & $\mathrm{kWh} /$ year & $1,924,523$ & $1,849,507$ \\
\hline \multicolumn{2}{|c|}{$\begin{array}{l}\text { Amount of electricity produced from biogas (2001) } \\
\text { and from biogas and natural gas (2002) }\end{array}$} & $\mathrm{kWh} /$ year & 421,664 & 846,000 \\
\hline \multirow{3}{*}{$\begin{array}{c}\text { Cost of } \\
\text { electricity } \\
(0.20 \mathrm{PLN} / \mathrm{kWh})\end{array}$} & $\begin{array}{l}\text { Variant without biogas } \\
\text { management }\end{array}$ & PLN/year & 384,904 & 369,901 \\
\hline & $\begin{array}{l}\text { Purchased electricity after } \\
\text { Balancing electricity from biogas }\end{array}$ & PLN/year & 300,572 & 200,701 \\
\hline & Cost of natural gas & PLN/year & $(-)$ & 98,075 \\
\hline & Savings & PLN/year & 84,332 & 71,125 \\
\hline
\end{tabular}

Currency Exchange Rate of 10/08/2021 PLN/Euro: 4.61.

In 2001 , the generating set provided $22 \%$ of the wastewater treatment plant's electricity demand, while in 2002 it provided 46\%. The financial savings were slightly less, but an increase in the amount of recovered heat was achieved. In subsequent years, this type of energy management made it possible to maintain prices for contractors for the collection and wastewater treatment, and to earn a profit, despite regular increases in electricity and natural gas prices. In 2006, a second generator set was purchased with an electrical capacity of $220 \mathrm{~kW}$ and a thermal capacity of $275 \mathrm{~kW}$. One of them worked only with natural gas and the other with biogas or alternatively with natural gas. Since that year, electricity production at the wastewater treatment plant has increased significantly. The cost of purchasing natural gas has risen, but the balance in terms of heat and electricity 
production has definitely improved. The condition imposed by the electricity supplier required a minimum of $20 \%$ of electricity to be purchased from ENEA.

A milestone in the energy independence of the Gubin-Guben Wastewater Treatment Plant was the award in 2011 of a concession for the production and sale of electricity generated from biogas and natural gas. Energy from biogas was recognised as clean energy and was awarded a "green certificate". Since 2012, the annual production of electricity from biogas and natural gas has been gradually increased, and the surplus is sold to the grid, generating additional revenue. The production of electricity from biogas was at a level of 450-675 MW/year, and this is a source of additional revenue within the framework of the energy certificates of origin "green certificates", and sales on the energy exchange.

In 2020, 34,810 tonnes of thickened sewage sludge were submitted for methane fermentation at the Gubin-Guben wastewater treatment plant. After anaerobic stabilization and mechanical dewatering, 2517 tonnes of sewage sludge was left for agricultural use. The fermentation process produced $324,475 \mathrm{~m}^{3}$ of biogas, of which $1702 \mathrm{~m}^{3}$ was burned in a gas flare. Therefore, $322,773 \mathrm{~m}^{3}$ of biogas was burned in gas engines and $675 \mathrm{MWh}$ of electricity was produced. The methane content in biogas ranges from 62 to $65 \%, \mathrm{CO}_{2}$ content from 37 to $34 \%$, and the remaining gases are $1 \%$. The average calorific value of biogas is $22,500 \mathrm{~kJ} / \mathrm{m}^{3}$. In addition, the engines, burning $145,000 \mathrm{~m}^{3}$ of natural gas, produced $493 \mathrm{MWh}$ of electricity. The calorific value of GZ 50 natural gas is $31,000 \mathrm{~kJ} / \mathrm{m}^{3}$.

\subsection{Step 2-Solar Photovoltaic Power Plant}

In 2015, a $250 \mathrm{~kW}$ solar photovoltaic power plant (PV) was built using the wastewater treatment plant's own financial resources. Since 30 June 2016, green energy has been produced from solar energy (Figure 5).

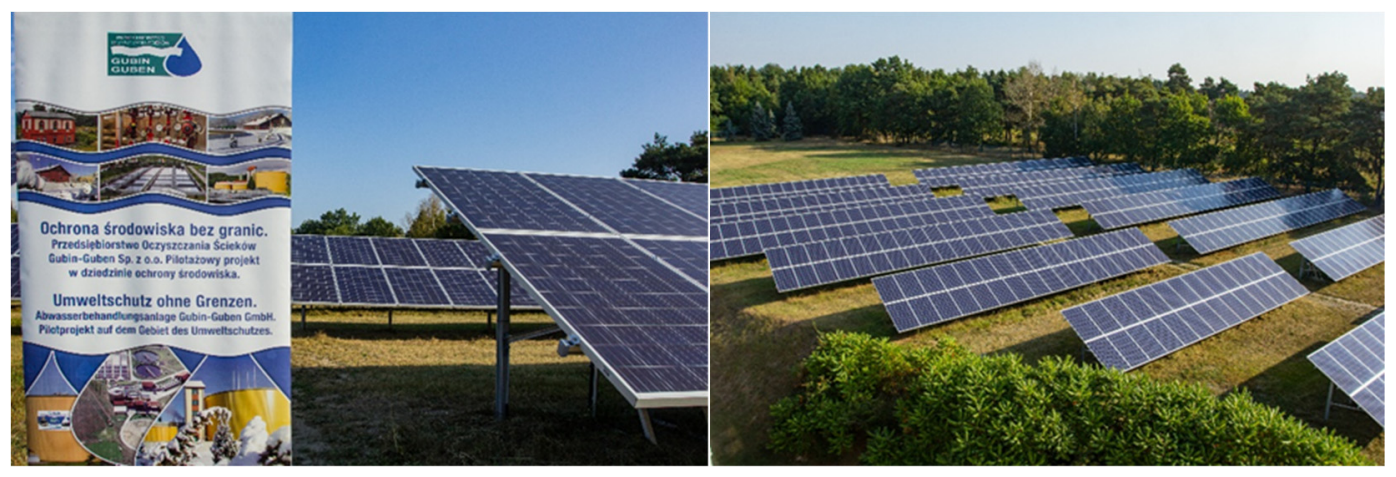

Figure 5. Solar photovoltaic power plant (photo by WWTP's Archive).

After several years of technical and billing terms and conditions, in 2020, the GubinGuben WWTP received new technical terms and conditions from the electricity supplier (ENEA), which finally allowed the power supply of the WWTP to be switched to a hybrid system, i.e., one power connection will be supplied simultaneously by two power sources (biogas/natural gas and PV installation). As a result of this arrangement, 100\% of the electricity produced is used for the company's own needs, and only the final excess is sold to the grid. The staff time spent on maintenance and keeping the PV working efficiently during the year is less when compared to the time that has to be spent on servicing the biogas and gas generating sets. The economic effects have proven to be very promising. The first three years of operation of the PV plant produced very good production results (Figure 6). In 2020, the PV plant system was put into operation, expanded to a capacity of $475 \mathrm{~kW}$. 


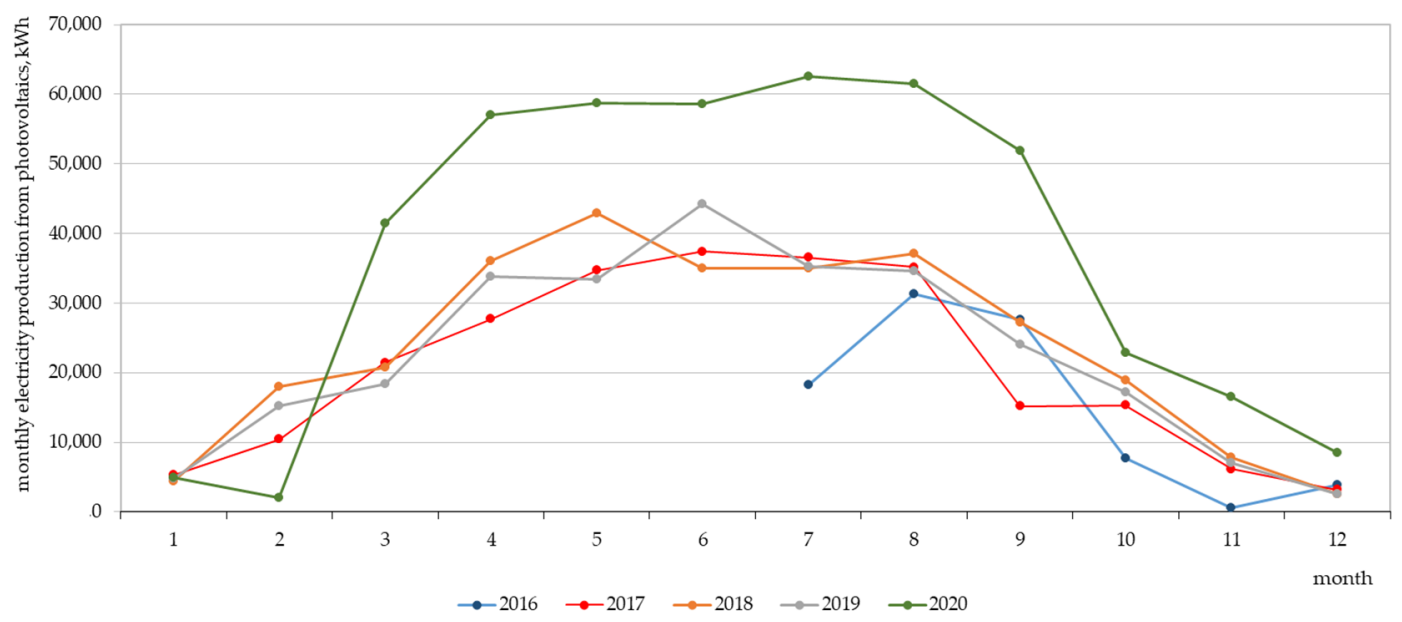

Figure 6. Monthly photovoltaic electricity production.

In 2020, 446 MWh of electricity was produced in the PV installation. Photovoltaic electricity production at a consistently high level is achieved between April and September. In 2020, this averaged 58,392 $\mathrm{kWh} /$ month during this period, with a maximum value in July of $62,556 \mathrm{kWh} /$ month. The average based on achievements throughout the year was $37,230 \mathrm{kWh} /$ month. Below 10,000 kWh/month was achieved only in the winter months of December, January, and February.

\subsection{Step Three-Geothermal Resources}

Analysis of the amount of heat consumed in the wastewater treatment plant facilities has shown that transporting heat via underground pipelines from the boiler house located in the sludge dewatering building about $200 \mathrm{~m}$ away from the office complex results in significant heat losses. The economic balance showed that an independent heat supply to the buildings of the office and workshop complex would result in large savings. In 2018, two hybrid heat pumps of heating power $39.9 \mathrm{~kW}$ and electric power $17.8 \mathrm{~kW}$ each were installed, securing the heat demand of the office and workshop complex. Heat pumps set operating parameters: COP 4.49, annual efficiency factor SPF 4.3, number of operating hours of the pumps during the year $=2445 \mathrm{~h} /$ year. The heat is used for heating: a social and office building (heat demand $\mathrm{Q}=70.30 \mathrm{~kW}$ ), a workshop and garage building (heat demand $Q=19.71 \mathrm{~kW}$ ), the total usable area is $1008 \mathrm{~m}^{2}$, and the volume is $434,905 \mathrm{~m}^{3}$.

In addition, the heat pump system provided two heat storage tanks, each with a capacity of $1000 \mathrm{dm}^{3}$. During the day, when there is a large excess of clean electricity produced, the water is heated to $85^{\circ} \mathrm{C}$ by electric heaters. The pumps are then not in operation. At night, the stored $2000 \mathrm{dm}^{3}$ of $85^{\circ} \mathrm{C}$ water is sufficient to provide the heat needed to heat the office and workshop complex. The tanks additionally contribute to shortening the operation time of heat pumps and saving energy purchased from the power grid per year.

In winter, the heat pumps are additionally switched on at very low temperatures. The pumps use heat from nine boreholes almost 200 m deep. In 2020, two tanks were added, each with $5000 \mathrm{dm}^{3}$, which are heated by solar-powered electric heaters and accumulate hot water during the day, which is used at night to supply a separate digester.

The total annual heat production of the pumps is $219,655 \mathrm{kWh}$, while the total annual electricity consumption of the heat pumps $=47,581 \mathrm{kWh}$. The cost of heat generation, assuming the use of own electricity obtained from the photovoltaic installation and biogas, is zero PLN.

\section{Discussion}

Between 1999 and 2021, the share of electricity produced at the Gubin-Guben WWTP in total electricity consumption increased steadily. The amount of electricity produced 
and purchased from the power grid is summarised in Figure 7. In 2020, full energy independence of the WWTP was achieved. The amount of electricity produced during the year exceeded its demand.

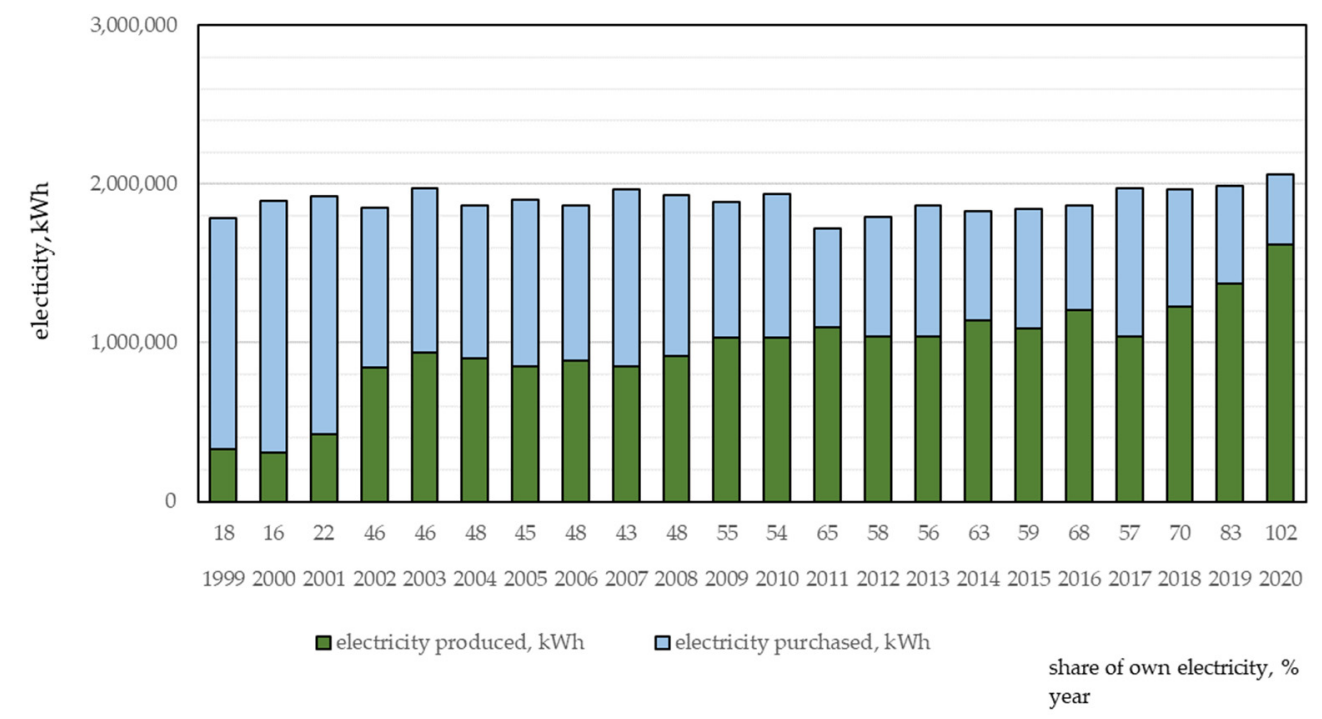

Figure 7. Electricity produced and purchased from the grid in the years 1999-2021.

Figure 8 shows the amount of energy produced by the Block Heat and Power Plant (BHKW) and the photovoltaic installation, the amount of electricity purchased, and the amount of raw sewage from 2000 to 2020. Figure 8 also shows the energy indicators in terms of the amount of electricity $(\mathrm{kWh})$ used to treat $1 \mathrm{~m}^{3}$ of sewage, taking into account the total energy consumption of the WWTP.

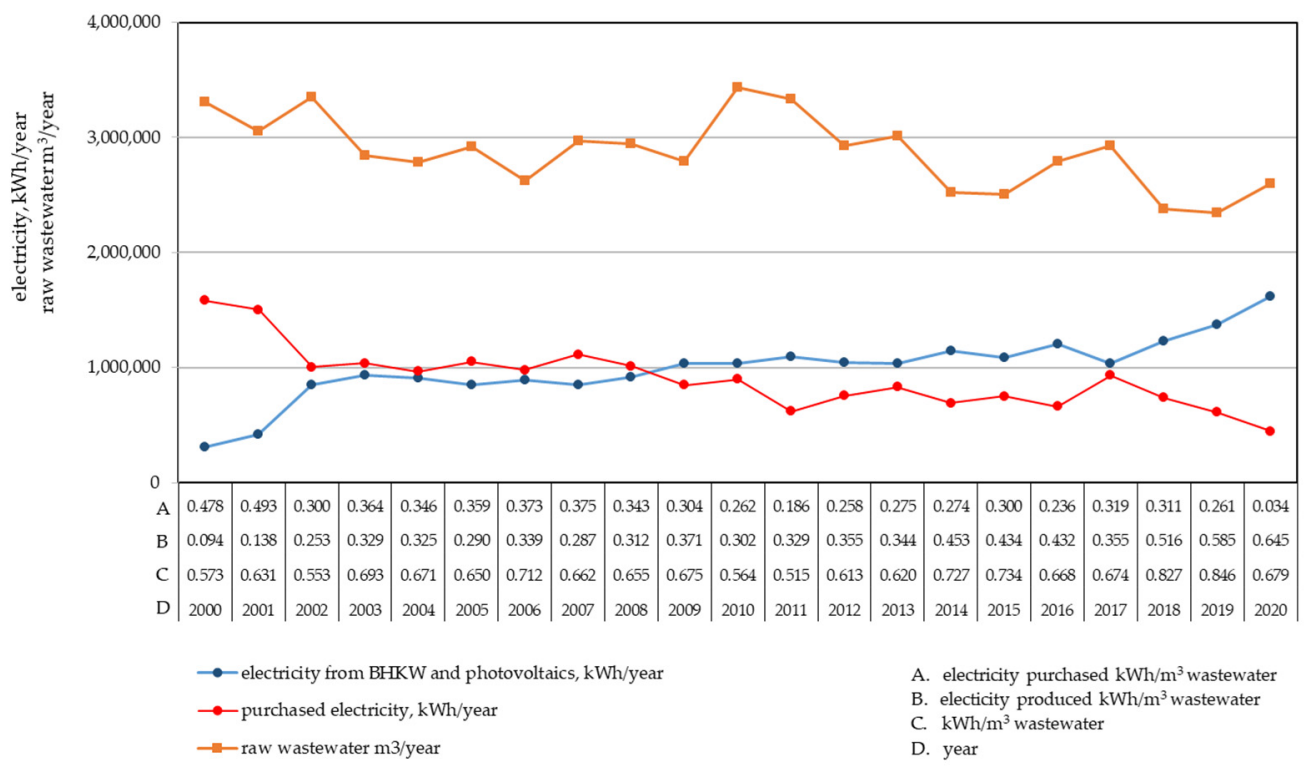

Figure 8. Amount of energy produced by BHKW and photovoltaic plant system, electricity purchased, and raw sewage in the years 2000-2020.

The consumption of electricity required to treat $1 \mathrm{~m}^{3}$ of wastewater in Gubin-Guben WWTP varied between 2000 and 2020 from 0.573 to $0.846 \mathrm{kWh} / \mathrm{m}^{3}$. As indicated by data in the literature, this indicator varies in a wide range of values $\left(0.30\right.$ to $\left.1.2 \mathrm{kWh} / \mathrm{m}^{3}\right)$ depending on the equipment of the facilities and the technology of wastewater treatment and sludge treatment $[38,39]$. In the report of the Polish Waterworks Chamber of Com- 
merce, the energy-intensity index for the Polish WWTPs, fixed at $0.71-1.04 \mathrm{kWh} / \mathrm{m}^{3}$ (data for 2017) [40], can be found. In the selected Polish WWTPs, the energy index is: the Rzeszów WWTP $0.865 \mathrm{kWh} / \mathrm{m}^{3}$ [41], the Krosno WWTP 0.61-1.11 kWh/m $\mathrm{m}^{3}$ [42], the Opole WWTP $0.723 \mathrm{kWh} / \mathrm{m}^{3}$ [43], the Iława WWTP 0.812-1.370 kWh $/ \mathrm{m}^{3}$ [2], the Lublin WWTP $0.421 \mathrm{kWh} / \mathrm{m}^{3}$ (consumption of electricity only for aeration system) [44].

In 2020, the consumption of electricity required to treat $1 \mathrm{~m}^{3}$ of wastewater in GubinGuben WWTP was $0.679 \mathrm{kWh}$ taking into account all points of demand for electricity, including non-technological ones.

Many authors point out that the energy assessment of wastewater treatment plants using this parameter seems to be misleading, as underestimated values are obtained in facilities with significant rainwater inflow $[1,5,38]$. Therefore, it is more meaningful to use indices for energy inputs related to the removal of specific pollutant loads, e.g., $\mathrm{BOD}_{5}$ or total nitrogen.

Figures 9 and 10 show the amount of energy produced by the BHKW and the PV plant, the electricity purchased, and the $\mathrm{BOD}_{5}$ and total nitrogen removed between 2000 and 2020, respectively. Data on energy indices per amount of electricity (kWh) required to remove $1 \mathrm{~kg}$ of $\mathrm{BOD}_{5}$ and $1 \mathrm{~kg}$ of total nitrogen are also presented.

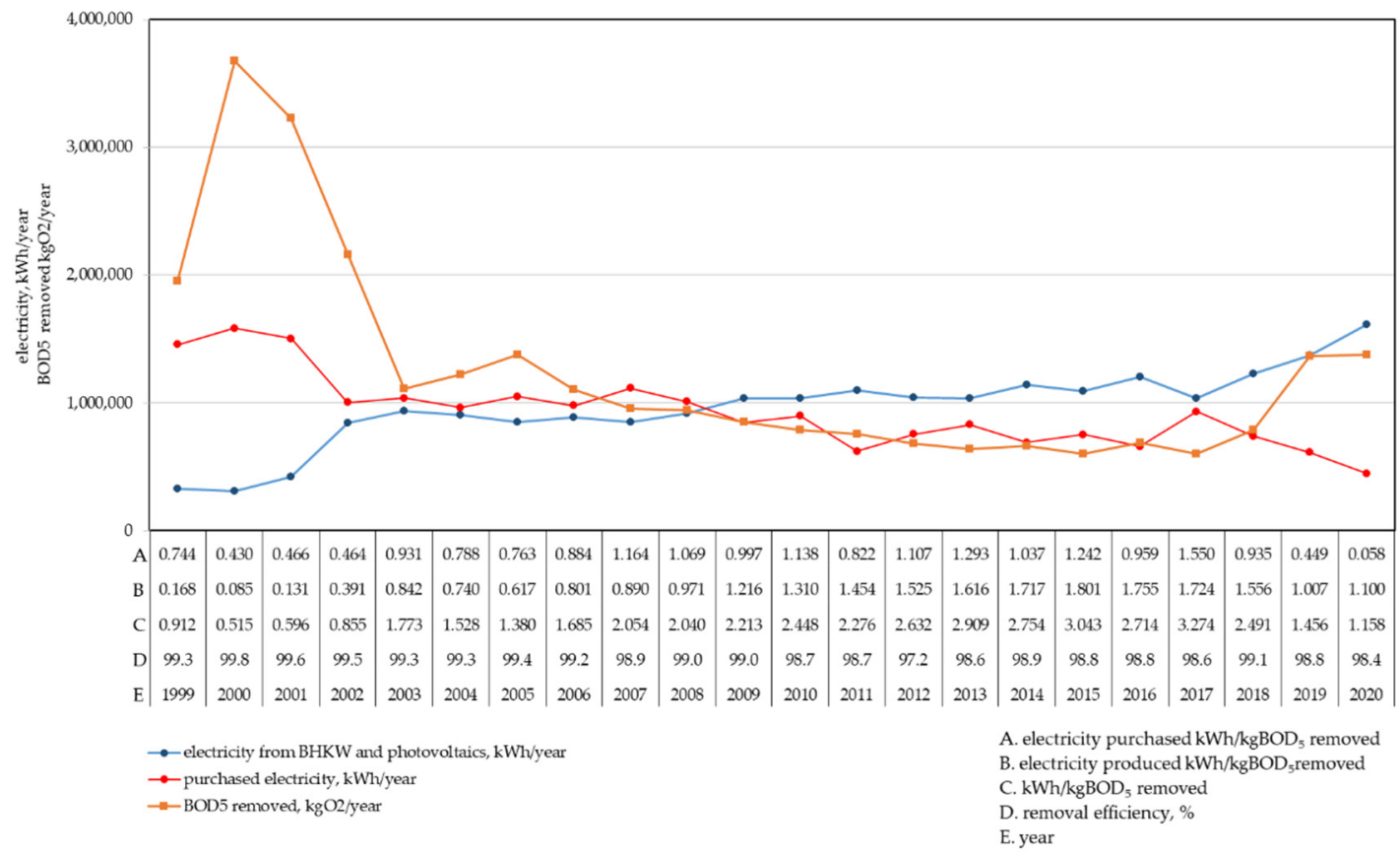

Figure 9. Amount of energy produced in $\mathrm{BHKW}$ and photovoltaic plant system, electricity purchased and $\mathrm{BOD}_{5}$ removed in the years 2000-2020.

In 2020, the electricity consumption index was $1.16 \mathrm{kWh} / \mathrm{kg}$ of $\mathrm{BOD}_{5}$ removed with a treatment efficiency of $98.4 \%$. However, for total nitrogen it was $12.51 \mathrm{kWh} / \mathrm{kg}$ of total nitrogen removed with a treatment efficiency of $88.6 \%$. According to Fighir et al. [45], for the four wastewater treatment plants analysed, the electricity consumption was found to be: $1.36 \mathrm{kWh} / \mathrm{kg} \mathrm{BOD}_{5}$ removed $(2710164 \mathrm{PE}), 1.51 \mathrm{kWh} / \mathrm{kg} \mathrm{BOD}_{5}$ removed (52158 PE), $1.92 \mathrm{kWh} / \mathrm{kg} \mathrm{BOD}_{5}$ removed (609601 PE), and $0.98 \mathrm{kWh} / \mathrm{kg} \mathrm{BOD}_{5}$ removed (524158 PE). In the selected Polish WWTPs, the energy intensity is: the Rzeszów WWTP from 1.03 to $1.57 \mathrm{kWh} / \mathrm{BOD}_{5}$ [41], the Opole WWTP $1.66 \mathrm{kWh} / \mathrm{BOD}_{5}$ [43], the Iława WWTP 0.92-2.13 kWh/BOD 5 [2]. In contrast, Christoforidou et al. [46] determined energy factors for size classes of wastewater treatment plants based on the Directive 91/271/EEC: Class A for P.E. > 100,000, Class B for 100,000 > P.E. > 10,000, Class C for 10,000 > P.E. > 2000, and Class D for P.E < 2000. In the A Class, WWTPs' specific energy values for organic load removal were found to be $5.95 \mathrm{kWh} / \mathrm{kg} \mathrm{N}$, B Class WWTPs $11.5 \mathrm{kWh} / \mathrm{kg} \mathrm{N}$, while C-D Class WWTPs are the most energy consuming with $18.46 \mathrm{kWh} / \mathrm{kg}$ N. If about $300 \mathrm{MWh}$ 
estimated for non-technological service are subtracted from the total amount of energy used these indicators will be definitely different, because, e.g., for wastewater treatment it will be $0.50 \mathrm{kWh} / \mathrm{m}^{3}$, for total nitrogen removal $\mathrm{N}$ it will be approx. $11.23 \mathrm{kWh} / \mathrm{kgN}$, and for $\mathrm{BOD}_{5}$ it will be $0.94 \mathrm{kWh} / \mathrm{kg} \mathrm{BOD}_{5}$.

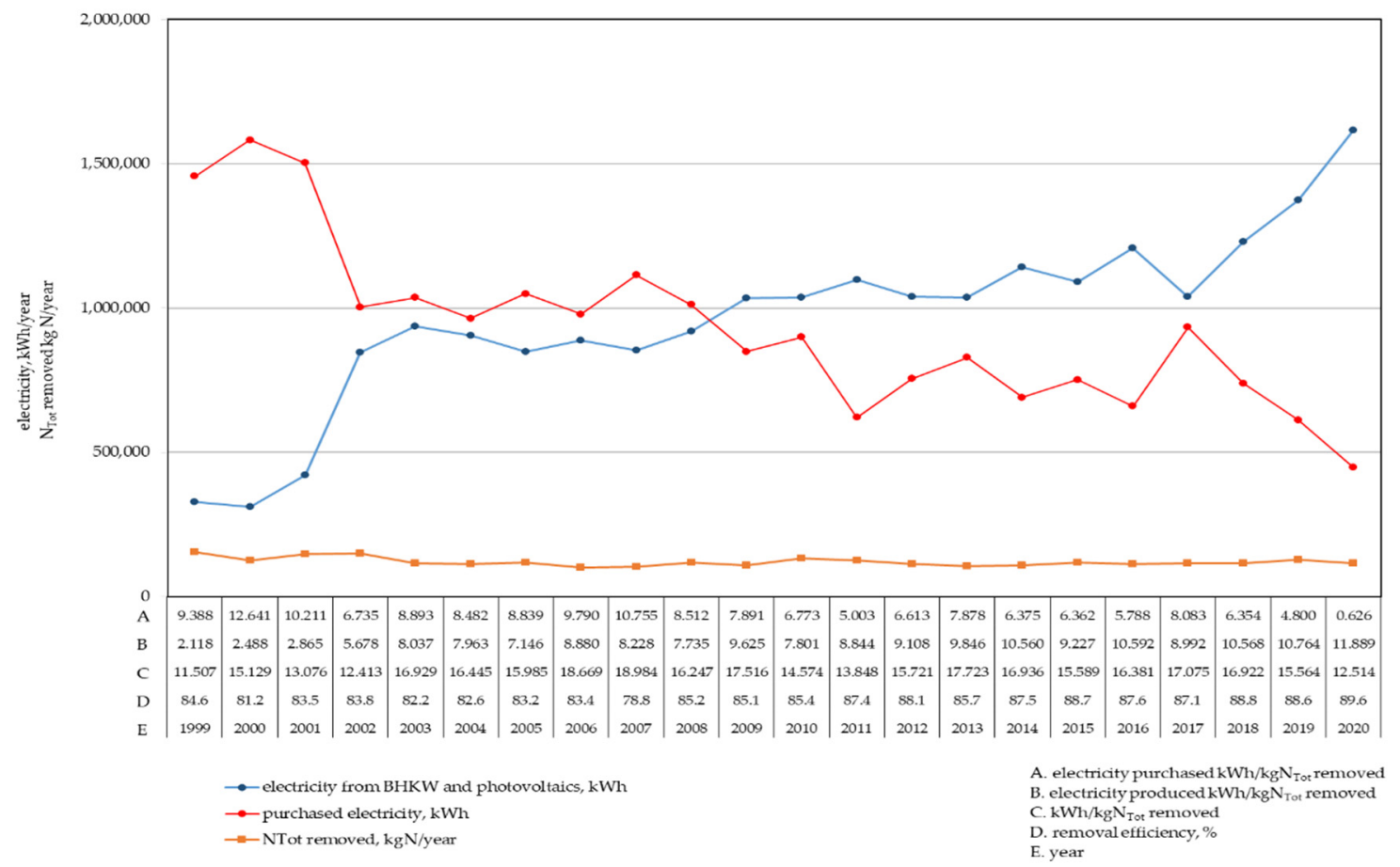

Figure 10. Amount of energy produced in BHKW and photovoltaic plant system, electricity purchased and total nitrogen removed in the years 2000-2020.

Electricity consumption in the Gubin-Guben WWTP, which was recorded, is the energy used both for the technological process and for servicing the needs of the office, workshop, canteen, area lighting, etc.

Additional investments made in recent years, such as the replacement of devices with energy-saving solutions (blowers, centrifuges), meant that in 2020, the Gubin-Guben wastewater treatment plant consumed 1596 MWh of electricity for operational and social and office purposes. This consumption is lower than in previous years.

An economic analysis of the profits resulting from the production of energy from renewable sources, the costs incurred for energy purposes in 2020 and a comparison with the costs that would be incurred without investments enabling the recovery of electricity and heat from biogas, natural gas, PV and geothermal energy are summarized in Table 3.

In the current situation, the price for the treatment of $1 \mathrm{~m}^{3}$ of wastewater and the management of sewage sludge in the Gubin-Guben WWTP is 1.50 PLN net for the Polish side and 0.70 EUR net for the German side. The generated net profit ensures financial liquidity at the level of 5.87. This can be regarded as an excellent result for a municipal enterprise which has to carry out its own tasks for the commune and works as a "nonprofit" company. In the absence of investments enabling the recovery of electricity and heat from biogas, natural gas, PV energy and geothermal energy, the cost of treating $1 \mathrm{~m}^{3}$ of wastewater and managing sewage sludge would be PLN 2.10 net for the Polish side and EUR 0.85 net for the German side, respectively. This is an indisputable argument for the rightness of investing in renewable energy sources and independence of WWTP from external energy suppliers. 
Table 3. Economic analysis of the costs of obtaining energy in WWTP Gubin-Guben.

\begin{tabular}{|c|c|c|}
\hline No. & Economic Analysis Component & Value \\
\hline \multicolumn{3}{|c|}{2020} \\
\hline 1 & Electricity sold to the grid & $\begin{array}{l}466,511 \mathrm{kWh} \cdot 0.17 \mathrm{PLN} / \mathrm{kWh}=79,307 \\
\text { PLN/y }\end{array}$ \\
\hline \multirow[t]{2}{*}{2} & $\begin{array}{c}\text { Sale of "green certificates" from } \\
\text { biogas } 675,335 \mathrm{kWh} \text { and from PV } \\
446,766 \mathrm{kWh}\end{array}$ & $\begin{aligned} 1,122,101 \mathrm{kWh} \cdot & 0.14 \mathrm{PLN} / \mathrm{kWh}=157,094 \\
& \text { PLN } / \mathrm{y}\end{aligned}$ \\
\hline & Total profits in PLN & 236,401 PLN/y \\
\hline 3 & Electricity purchase cost & $447,269 \cdot 0.56 \mathrm{PLN} / \mathrm{kWh}=249,031 \mathrm{PLN} / \mathrm{y}$ \\
\hline \multirow[t]{2}{*}{4} & Natural gas purchase cost & $178,125 \mathrm{~m}^{3} \cdot 1.46 \mathrm{PLN} / \mathrm{m}^{3}=260,526 \mathrm{PLN} / \mathrm{y}$ \\
\hline & Total costs in PLN & 509,557 PLN/y \\
\hline \multicolumn{2}{|c|}{$\begin{array}{l}\text { Energy cost covering } 100 \% \text { of electricity and heat } \\
\text { demand } \\
\text { and the cost of energy for the treatment of } 1 \mathrm{~m}^{3} \\
\text { of wastewater }\end{array}$} & $\begin{array}{c}509,557 \text { PLN } / y-236,401 \mathrm{PLN} / \mathrm{y}=273,156 \\
\text { PLN } / \mathrm{y} \\
273,156 \mathrm{PLN} / \mathrm{y} / 2,597,056 \mathrm{~m}^{3} \text { raw } \\
\text { wastewater } / \mathrm{y}=0.10 \mathrm{PLN} / \mathrm{m}^{3}\end{array}$ \\
\hline \multicolumn{3}{|c|}{$\begin{array}{l}\text { Analysis without investments enabling the recovery of electricity and heat from biogas, } \\
\text { natural gas, PV and geothermal energy }\end{array}$} \\
\hline 8 & Electricity purchase cost & $\begin{array}{c}1,596,170 \mathrm{kWh} / \mathrm{y} \cdot 0.56 \mathrm{PLN} / \mathrm{y}=894,415 \\
\text { PLN } / \mathrm{y}\end{array}$ \\
\hline 9 & Natural gas purchase cost & $200,000 \mathrm{~m}^{3} \cdot 1.46 \mathrm{PLN} / \mathrm{m}^{3}=292,000 \mathrm{PLN} / \mathrm{y}$ \\
\hline \multicolumn{2}{|c|}{$\begin{array}{l}\text { Energy cost covering } 100 \% \text { of electricity and heat } \\
\text { demand } \\
\text { and the cost of energy for the treatment of } 1 \mathrm{~m}^{3} \\
\text { of wastewater }\end{array}$} & $\begin{array}{c}894,415 \text { PLN } / y+292,000 \mathrm{PLN} / \mathrm{y}=1,186,415 \\
\text { PLN/y } \\
1,186,415 \mathrm{PLN} / \mathrm{y} / 2,597,056 \mathrm{~m}^{3} \mathrm{raw} \\
\text { wastewater } / \mathrm{y}=0.46 \mathrm{PLN} / \mathrm{m}^{3}\end{array}$ \\
\hline
\end{tabular}

Currency Exchange Rate of 10/08/2021 PLN/Euro: 4.61.

Despite the very good energy effects, the strategy of the WWTP's operation still includes priority further actions, which, with the recent rapid prices for electricity, will ensure the unchanging price for both cities, Gubin and Guben, for wastewater treatment and financial security for the company. Currently, the construction of a photovoltaic installation has started on all roofs of buildings in the WWTP, as an autonomous network for a given building. This will additionally account for about $160 \mathrm{~kW}$ of installed power, which during the day will relieve the energy demand of a given building and devices operating in it. It will also have a direct impact on reducing the amount of purchased natural gas.

The procedure for extending the permit for the treatment of biowaste in the digestion bioreactor is also underway. Currently, the fermentation chamber is underloaded. Supplementing the batch will cause the daily production of biogas to increase at least two times. Thus, the production of own electricity from biogas will reduce the current consumption of natural gas by about $50-70 \%$ and the cost of its purchase.

Another investment is the purchase of an "energy bank" with a capacity of approximately $180 \mathrm{~kW}$. This investment will guarantee, during periods of lack of sun, when the photovoltaic installation is not able to provide the power required by the WWTP, a smooth operation, instead of buying energy or keeping gas engines in constant excess of energy production.

\section{Conclusions}

The heat and electricity generated by hybrid systems affect the final costs of wastewater treatment. The electricity consumption for treating $1 \mathrm{~m}^{3}$ of wastewater was $0.679 \mathrm{kWh}$ at the Gubin-Guben WWTP in 2020. The combined production of electricity and heat from biogas as well as the generation of electricity by photovoltaic system makes it possible to 
achieve a surplus of heat in relation to demand and to cover the demand for electricity for the entire WWTP with the possibility of selling it to the grid. The operational experience of the analysed WWTP in 2020 will make it possible to optimise energy management as much as possible. The hybrid system allows for the fact that during the day, when the photovoltaic system is operating at full capacity, the WWTP uses 100\% of its own electricity, and the excess is partly fed into the heaters for heat production in the heat storage tanks, and partly returned to the grid.

The possibility of maintaining a low price for wastewater treatment for recipients is an indisputable argument for the need to invest in renewable energy sources and the way to independence of the WWTP from external energy suppliers.

Anaerobic techniques are not only a solution to the environmental problem of sewage sludge, but also provide economic benefits from the production of high-energy digestion gas. Such solutions should become an alternative for wastewater treatment plants. Technological systems of sewage sludge management and biogas utilisation, combined in hybrid systems with photovoltaic installations, can be a source of inspiration in the search for optimal solutions in the energy management of wastewater treatment plants.

Author Contributions: Conceptualization, S.M., D.B., M.M. and E.P.-K.; methodology, S.M. and D.B.; validation, S.M., D.B., M.M. and E.P.-K.; formal analysis, S.M. and D.B.; resources, D.B.; writing-original draft preparation, S.M., D.B., M.M. and E.P.-K.; writing-review and editing, S.M.; visualization, S.M. and E.P.-K.; supervision, S.M.; project administration, S.M. All authors have read and agreed to the published version of the manuscript.

Funding: This research received no external funding; The APC was funded by the Marshal's Office of Lubuskie Province in the framework of the competition Small Grants for Public Universities from Lubuskie Province.

Institutional Review Board Statement: Not applicable.

Informed Consent Statement: Not applicable.

Conflicts of Interest: The authors declare no conflict of interest.

\section{References}

1. Energy Data Management Manual for the Wastewater Treatment Sector; DOE/EE-1700; US Department of Energy's Office of Energy Efficiency and Renewable Energy under Oak Ridge National Laboratory Contract No. DE-AC05-00OR22725: 2017. Available online: https: / / www.energy.gov (accessed on 25 September 2021).

2. Masłoń, A.; Czarnota, J.; Szaja, A.; Szulczyk-Cieplak, J.; Łagód, G. The Enhancement of Energy Efficiency in a Wastewater Treatment Plant through Sustainable Biogas Use: Case Study from Poland. Energies 2020, 13, 6056. [CrossRef]

3. Siatou, A.; Manali, A.; Gikas, P. Energy Consumption and Internal Distribution in Activated Sludge Wastewater Treatment Plants of Greece. Water 2020, 12, 1204. [CrossRef]

4. Gruber-Glatzl, W.; Brunner, C.; Meitz, S.; Schnitzer, H. From the Wastewater Treatment Plant to the Turnstiles of Urban Water and District Heating Networks. Front. Sustain. Cities 2020, 2, 523698. [CrossRef]

5. Yang, J.; Chen, B. Energy efficiency evaluation of wastewater treatment plants (WWTPs) based on data envelopment analysis. Appl. Energy 2021, 289, 116680. [CrossRef]

6. Zessner, M.; Lampert, C.; Kroiss, H.; Lindtner, S. Cost comparison of wastewater treatment in Danubian countries. Water Sci. Technol. 2010, 62, 223-230. [CrossRef]

7. Capodaglio, A.G.; Olsson, G. Energy Issues in Sustainable Urban Wastewater Management: Use, Demand Reduction and Recovery in the Urban Water Cycle. Sustainability 2020, 12, 266. [CrossRef]

8. Nagpal, H.; Spriet, J.; Krishna Murali, M.; McNabola, A. Heat Recovery from Wastewater-A Review of Available Resource. Water 2021, 13, 1274. [CrossRef]

9. Qadir, M.; Drechsel, P.; Jiménez Cisneros, B.; Kim, Y.; Pramanik, A.; Mehta, P.; Olaniyan, O. Global and regional potential of wastewater as a water, nutrient and energy source. Nat. Resour. Forum. 2020, 44, 40-51. [CrossRef]

10. $\operatorname{COM(2014)~15final.~A~Policy~Framework~for~Climate~and~Energy~in~the~Period~from~} 2020$ to 2030; Publications Office of the European Union: Luxembourg, 2014.

11. COM(2016) 767 final/2. Proposal for a Directive of the European Parliament and of the Council on the Promotion of the Use of Energy from Renewable Sources (Recast); Publications Office of the European Union: Luxembourg, 2017.

12. Guo, Z.; Sun, Y.; Pan, S.-Y.; Chiang, P.-C. Integration of Green Energy and Advanced Energy-Efficient Technologies for Municipal Wastewater Treatment Plants. Int. J. Environ. Res. Public Health. 2019, 16, 1282. [CrossRef] [PubMed] 
13. Colmenar-Santos, A.; Zarzuelo-Puch, G.; Borge-Diez DGarcía-Diéguez, C. Thermodynamic and exergoeconomic analysis of energy recovery system of biogas from a wastewater treatment plant and use in a Stirling engine. Renew. Energy 2016, 88, 171-184. [CrossRef]

14. Myszograj, S. Biogas and Methane Potential of Pre-Thermally Disintegrated Bio-Waste. Energies 2019, 12, 3880. [CrossRef]

15. Myszograj, S. Produkcja Biogazu z Osadów Nadmiernych i Odpadów Komunalnych Dezintegrowanych Termicznie 2017; Instytut Inżynierii Środowiska Uniwersytetu Zielonogórskiego: Zielona Góra, Polish, 2017; ISBN 9788393761999. (In Polish)

16. Frijns, J.; Hofman, J.; Nederlof, M. The potential of (waste) water as energy carrier. Energy Convers. Manag. 2013, 65, 357-363. [CrossRef]

17. Logan, B.E. Simultaneous wastewater treatment and biological electricity generation. Water Sci. Technol. 2005, 52, 31-37. [CrossRef]

18. Guest, S.J.; Skerlos, J.L.; Barnard, M.B.; Beck, G.T.; Daigger, H. A new planning and design paradigm to achieve sustainable resource recovery from wastewater. Environ. Sci. Technol. 2009, 43, 6126-6130. [CrossRef]

19. Tarallo, S.; Shaw, A.; Kohl, P.; Eschborn, R. A Guide to Net-Zero Energy Solutions for Water Resource Recovery Facilities (ENER1C12); Water Environment Research Foundation (WERF): Alexandria, VA, USA, 2015.

20. Verstraete, W.; Van de Caveye, P.; Diamantis, V. Maximum use of resources present in domestic "used water". Bio-Resour. Technol. 2009, 100, 5537-5545. [CrossRef] [PubMed]

21. Statistics Poland, 2019: Energia ze Źródeł Odnawialnych w 2018 r. Available online: https://stat.gov.pl/en/topics/environmentenergy/energy/energy-from-renewable-sources-in-2018,3,11.html (accessed on 7 October 2021).

22. Scarlat, N.; Dallemand, J.-F.; Fahl, F. Biogas: Developments and perspectives in Europe. Renew. Energy 2018, 129, 457-472. [CrossRef]

23. Nowak, O.; Enderle, P.; Varbanov, P. Ways to optimize the energy balance of municipal wastewater systems: Lessons learned from Austrian applications. J. Clean. Prod. 2015, 88, 125-131. [CrossRef]

24. Cipolla, S.S.; Maglionico, M. Heat recovery from urban wastewater: Analysis ofv the variability of flow rate and temperature in the sewer of Bologna, Italy. Energy Procedia 2014, 45, 288-297. [CrossRef]

25. Schmid, F. Sewage water: Interesting heat source for heat pumps and chillers. In Proceedings of the 9th International IEA Heat Pump Conference, Zürich, Switzerland, 20-22 May 2008; pp. 1-12.

26. Hao, X.; Liu, R.; Huang, X. Evaluation of the potential for operating carbon neutral WWTPs in China. Water Res. 2015, 87, 424-431. [CrossRef] [PubMed]

27. Di Fraia, S.; Macaluso, A.; Massarotti, N.; Vanoli, L. Energy, exergy and economic analysis of a novel geothermal energy system for wastewater and sludge treatment. Energy Convers. Manag. 2019, 195, 533-547. [CrossRef]

28. Pochwała, S.; Kotas, P. Possibility of obtaining wastewater heat from a sewage treatment plant by the means of a heat pump-A case study. E3S Web. Conf. 2018, 44, 00144. [CrossRef]

29. Eurostat, European Statistics, Renewable Energy Statistics. Available online: https://ec.europa.eu/eurostat/statistics-explained/ index.php?title=Renewable_energy_statistics\#Share_of_renewable_energy_more_than_doubled_between_2004_and_2019 (accessed on 5 October 2021).

30. Zeng, S.; Jiang, C.; Ma, C.; Su, B. Investment efficiency of the new energy industry in China. Energy Econ. 2018, 70, 536-544. [CrossRef]

31. Tanveer, A.; Zeng, S.; Irfan, M.; Peng, R. Do Perceived Risk, Perception of Self-Efficacy, and Openness to Technology Matter for Solar PV Adoption? An Application of the Extended Theory of Planned Behavior. Energies 2021, 14, 5008. [CrossRef]

32. Maktabifard, M.; Zaborowska, E.; Makinia, J. Achieving energy neutrality in wastewater treatment plants through energy savings and enhancing renewable energy production. Rev. Environ. Sci. Biotechnol. 2018, 17, 655-689. [CrossRef]

33. Strazzabosco, A.; Kenway, S.J.; Lant, P.A. Solar PV adoption in wastewater treatment plants: A review of practice in California. J. Environ. Manag. 2019, 248, 109337. [CrossRef] [PubMed]

34. Ambriz-Díaz, V.M. Analysis of a sequential production of electricity, ice and drying of agricultural products by cascading geothermal energy. Int. J. Hydrog. Energy 2017, 42, 18092-18102. [CrossRef]

35. Rubio-Maya, C.; Díaz, V.A.; Martínez, E.P.; Belman-Flores, J.M. Cascade utilization of low and medium enthalpy geothermal resources - A review. Renew. Sustain. Energy Rev. 2015, 52, 689-716. [CrossRef]

36. Gu, Y.; Li, Y.; Li, X.; Luo, P.; Wang, H.; Wang, X.; Wu, J.; Li, F. Energy self-sufficient wastewater treatment plants: Feasibilities and challenges. Energy Procedia 2017, 105, 3741-3751. [CrossRef]

37. Yan, P.; Qin, R.; Guo, J.; Yu, Q.; Li, Z.; Chen, Y.; Shen YFang, F. Net-Zero-Energy Model for Sustainable Wastewater Treatment. Environ. Sci. Technol. 2017, 51, 1017-1023. [CrossRef]

38. Gikas, P. Towards energy positive wastewater treatment plants. J. Environ. Manag. 2017, 203, 621-629. [CrossRef]

39. Bodík, I.; Kubaská, M. Energy and sustainability of operation of a wastewater treatment plant. Environ. Protect. Eng. 2013, 39, 15-24. [CrossRef]

40. Chamber of Commerce "Polish Waterworks" (IGWP). Information Materials. 2020. Available online: https://www.igwp.org.pl (accessed on 25 September 2021).

41. Masłon, A. Analysis of energy consumption at the Rzeszów Wastewater Treatment Plant. In Proceedings of the International Conference on Advances in Energy Systems and Environmental Engineering (ASEE17), E3SWeb Conf, Wrocław, Poland, 2-5 July 2017; Volume 22, p. 00115. 
42. Trojanowicz, K.; Karamus, Ł. Energy utilization of biogas as an element of sewage sludge management in the wastewater treatment plant in Krosno. Forum Eksploatatora 2016, 4, 46-53. (In Polish)

43. Szczyrba, P.; Masłoń, A.; Czarnota, J.; Olszewski, K. Analysis of sewage sludge and biogas-energy management at the Opole wastewater treatment plant. Ecol. Eng. 2020, 21, 26-34. [CrossRef]

44. Kurek, E. Wykorzystanie strącania wstępnego do poprawy funkcjonowania gospodarki osadowej w oczyszczalni ścieków Hajdów w Lublinie. Forum Eksploatatora 2018, 5, 50-58. (In Polish)

45. Fighir, D.; Teodosiu, C.; Fiore, S. Environmental and Energy Assessment of Municipal Wastewater Treatment Plants in Italy and Romania: A Comparative Study. Water 2019, 11, 1611. [CrossRef]

46. Christoforidou, P.; Bariamis, G.; Iosifidou, M.; Nikolaidou, E.; Samaras Christoforidou, P. Energy Benchmarking and Optimization of Wastewater Treatment Plants in Greece. Environ. Sci. Proc. 2020, 2, 36. [CrossRef] 